The Originality of Plautus' Casina

Author(s): Shawn O'Bryhim

Source: The American Journal of Philology, Vol. 110, No. 1 (Spring, 1989), pp. 81-103

Published by: The Johns Hopkins University Press

Stable URL: http://www.jstor.org/stable/294954

Accessed: 11-06-2015 19:12 UTC

Your use of the JSTOR archive indicates your acceptance of the Terms \& Conditions of Use, available at http://www.jstor.org/page/ info/about/policies/terms.jsp

JSTOR is a not-for-profit service that helps scholars, researchers, and students discover, use, and build upon a wide range of content in a trusted digital archive. We use information technology and tools to increase productivity and facilitate new forms of scholarship. For more information about JSTOR, please contact support@jstor.org. 


\section{THE ORIGINALITY OF PLAUTUS' CASINA}

Throughout the history of Plautine scholarship, there has been a great deal of disagreement over how much of substance Plautus altered in his Greek originals. Although many scholars were originally of the opinion that "everything artistically satisfying is Greek in origin, everything defective and weak is Roman botching," today it is recognized that Plautus often made significant contributions to his sources. It is my intention to further this view by demonstrating that, in the Casina, Plautus carefully selected portions of two comedies, made major changes in them, blended in his own material, and molded the results into a coherent, tightly constructed plot. The end result bears little resemblance to the prologue's description of the Cas-

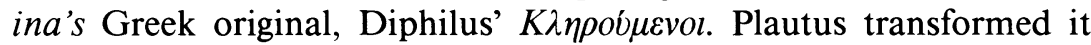
into a completely different play - a play that shows signs even of genius.

It has been suggested that the Casina is essentially a translation of its Greek original and that Plautus, if he made any changes at all, did nothing to alter the original's plot. ${ }^{2}$ A careful examination of the play reveals a number of clues which show that Plautus not only made substantial cuts in his Greek original, but also many significant additions to it. ${ }^{3}$

Lines 31-34 of the prologue give us the title and author of the

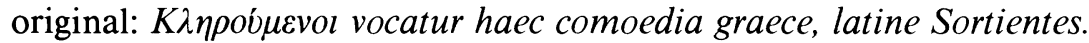
Diphilus hanc graece scripsit, postid rursum denuo latine Plautus cum latranti nomine. Scholars have assumed that the adverb denuo is merely a pleonasm ${ }^{4}$ and that Plautus ${ }^{5}$ is saying that he wrote it again,

${ }^{1}$ H. W. Prescott, “The Interpretation of Roman Comedy," CP 14 (1916) 145 , writing in opposition to this view.

${ }^{2}$ T. B. L. Webster, Studies in Later Greek Comedy (New York 1970) 164, M. Damen, The Comedy of Diphilos Sinopeus in Plautus, Terence, and Athenaeus (Diss. University of Texas at Austin 1985) 201-2, and, to a great extent, W. T. MacCary, "The Comic Tradition and Comic Structure in Diphilos' Kleroumenoi," Hermes 101 (1973) 194-208.

${ }^{3}$ For Plautus' method of reworking plays, see W. G. Arnott, "Menander, Plautus, Terence," Greece and Rome: New Surveys in the Classics 9 (1975) 32-38.

${ }^{4}$ For example, W. Thomas MacCary and M. M. Willcock, Casina (Cambridge 1976) 102, Nixon's translation of the Casina in the Loeb Classical Library (London 1917), and Gonzalez Lodge, Lexicon Plautinum (Leipzig 1924).

${ }^{5}$ It is generally agreed that Plautus wrote the entire prologue except for lines 5-

American Journal of Philology 110 (1989) 81-103 (C) 1989 by The Johns Hopkins University Press 
i.e., translated it, into Latin. Damen more ingeniously sees rursum denuo it as part of a joke: "The joke implies that there was a Latin version of the play before Diphilus wrote the original, so that Plautus could put it back again into Latin." ${ }^{.6}$ But in other plays, Plautus uses denuo in the sense of iterum or de integro. ${ }^{7}$ If we adopt this interpretation of denuo, the passage takes on a different meaning: 'Then Plautus wrote it in Latin from the ground up all over again'. Apparently Plautus is asserting that the Casina is not a translation, but a thorough reworking of the Greek original.

Other passages in the prologue support this interpretation. Lines 60-66 speak of the old man's son, Euthynicus, who is in love with Casina. When his father discovered Euthynicus' feelings for the girl, he sent him abroad. Then we are told: is, ne exspectetis, hodie in hac comoedia in urbem non redibit: Plautus noluit, pontem interrupit, qui erat ei in itinere (64-66). This comment could mean no more than that the standard theme of the returning son does not appear. But the phrase hodie in hac comoedia, when coupled with the rest of this state-

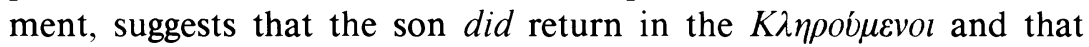
Plautus was responsible for his absence in hac comoedia, the Casina. ${ }^{8}$ This explains why Euthynicus is mentioned in the body of the play (262-265) not by name but by the word filius. Plautus has thereby avoided the confusion that might have been caused by the inclusion of another named but unseen character. When Euthynicus is men-

22 which were added for a revival performance in the second century. See MacCary and Willcock, op. cit., 97 and K. Abel, Die Plautusprologe (Diss. Frankfurt 1955) 55-61.

${ }^{6}$ Damen, op. cit., 247, n. 17.

${ }^{7}$ This usage is found at Amphitruo 317: illic homo me interpolabit meumque os finget denuo; Mostellaria 117:aedificantur aedes totae denuo; and Poenulus 79:revertor rursus denuo Carthaginem.

${ }^{8}$ Damen, op. cit., 207-208, however, believes that Euthynicus did not appear in the Greek play and that Plautus added the references to him to give his audience "a gruesome insight into Lysidamus' all-consuming lust. It is hardly credible that the originator of the story constructed the plot with Euthynicus in mind. ... A father who would openly admit that he had deprived his son of his beloved to service his own lust for one night has no place in comedy." The motif of the father stealing his son's girlfriend does indeed have a place in comedy. The best example is the final scene of the Asinaria, where the father takes his son's girlfriend not for the night, but for only a few hours with hilarious consequences. Furthermore, there are many repeated references to the father's "allconsuming lust" which give the audience a clear insight into the father's character, e.g., the homosexual allusions. What need is there, then, for what Damen himself points out (206) is a one-time reference (outside the prologue and epilogue) to Euthynicus, a character who does not even appear on stage? 
tioned by name in the prologue and epilogue, it is to tell the audience what not to expect-ne exspectetis (64). The most plausible reason for them to expect the appearance of a character named Euthynicus is that he was an important part of the Greek original-a part deleted by Plautus. ${ }^{9}$

Both the prologue (80-83) and the epilogue (1012-1014) provide us with information about Casina's fate. It will be discovered that she is a freeborn Athenian citizen, the daughter of Alcesimus and Myrrhina. She will then marry Euthynicus. Presumably, the slave in lines 37-44 who was to expose Casina but instead gave her to Cleustrata

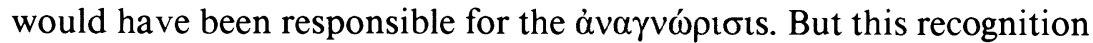
scene does not appear in the Casina.$^{10}$ It is condensed and relegated to the epilogue. Damen believes that the reference to a recognition scene was added by Plautus and that such a scene was not part of the

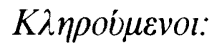

Without the resolution of Casina's fate by a recognition and marriage, there is no such assurance in the play itself that Lysidamus will not continue to pursue her." This information adds a backdrop of virtue and morality to a story which, without it, is little more than a racy tale of an old man chasing a young girl and the humiliation he suffers at his wife's hands. $^{12}$

But if the recognition scene, or at least a reference to it, did not occur in the Greek original, what would be its plot? "A racy tale of an old man chasing a young girl and the humiliation he suffers at his wife's

${ }^{9}$ Evidence that some Romans may have known Plautus' originals before he adapted them may be found by comparing the Bacchides and Menander's Ais

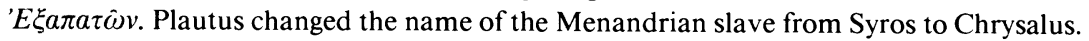
At Bacchides 649-50, he makes Chrysalus say non mihi isti placent Parmenones, Syri, qui duas aut tris minas auferunt eris. Those who had read or seen Menander's play would have been amused by the reference to the slave in the original, Syros. See E. W. Handley, Menander and Plautus: A Study in Comparison (London 1968) 9, Arnott, op. cit., 39. Also R. Hunter, The New Comedy of Greece and Rome (Cambridge 1985) 19, on the performance of Greek plays in southern Italy and Sicily.

${ }^{10}$ It is very likely that Plautus was responsible for the fact that the slave in morbo cubat (37). For those who knew the Greek original, this joke accounts for the absence of both the slave and the recognition scene. See MacCary and Willcock, op. cit., 103.

"But at 1001-1003, the senex himself promises not to pursue Casina and gives his wife the right to beat him if he does.

${ }^{12}$ Damen, op. cit., 209. 
hands." There is no reason to assume that the Romans, who were accustomed to bawdy Atellane farces and Fescennine verse, would have any need for a "backdrop of virtue and morality" in a comoedia palliata, especially such a thin backdrop. ${ }^{13}$ We must assume that the

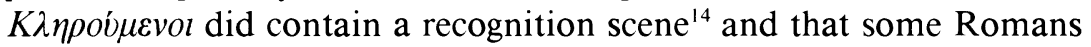
were familiar with it. It is for their benefit that Plautus describes the differences between the two versions.

A stock phrase in line 1006 provides further evidence of this alteration. Cleustrata agrees to forgive her husband hanc ex longa longiorem ne faciamus fabulam. On the face of it, this is only a deliberate breach of the dramatic illusion for humorous effect, a technique which Plautus favored from time to time. But in this case we can press the reference harder. If Plautus had only removed the recognition scene without making any additions of his own, his original would have been substantially longer than the 1018 lines of the Casina. It would have included the return of Euthynicus, probably some confrontation with or deception of his father, the slave's revelation of Casina's freeborn status, and the marriage announcement. ${ }^{15}$ When added to the existing 1018 lines, this would have made for a play of massive size, far longer

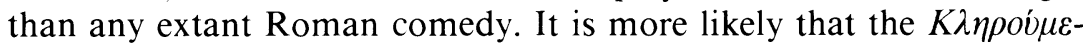
vol was of average length, that Plautus cut out the recognition scene and, left with a much shorter play, made additions of his own. ${ }^{16}$ And as we shall see, these additions are what make the work Plautus' own.

Thus, one of the puzzling aspects of the Casina is the inconsistencies in the characters of Chalinus and Myrrhina. In the beginning of the play, Chalinus is the typical servus callidus determined to thwart the plans of his master while Myrrhina is the epitome of a loyal wife. But at the end of the play it is the women, not Chalinus, who conceive the plan for the deception of the senes. Chalinus is merely the instrument through which the trick is carried out, while the women have taken over the role of the servus callidus (759-779). Moreover, in the

13 "Much of what some moderns have considered shocking and abnormal would have seemed to the Roman spectator as a perfectly proper subject for ridicule and laughter. Their reactions were not hampered by centuries of Christian and Puritan morality." George E. Duckworth, The Nature of Roman Comedy (Princeton 1955) 295.

${ }^{14}$ MacCary and Willcock, op. cit., 103 and 109.

${ }^{15}$ Webster, op. cit., 163, reconstructs such a scenario, but believes that Diphilus did not include it because it would have slowed the action.

${ }^{16}$ Arnott, op. cit., 37 and n. 39. 
first act Myrrhina strongly disagrees with Cleustrata's opposition to her husband (198-210), but later she wholeheartedly assists Cleustrata in her revenge. Minor inconsistencies in Plautine comedies may be overlooked, but these characters have changed so drastically that their later behavior could have been drawn from a completely different play. That may, indeed, have happened.

In the prologue to the Andria, Terence implies that contaminare is to mold segments of two Greek originals into one Latin play and that Plautus, among others, did this. ${ }^{17}$ In the Adelphoi, he admits that he used a scene which Plautus, in the Commorientes, deleted from his original, Diphilus' $\Sigma v v a \pi o \theta v \dot{\eta} \sigma \kappa o v \tau \varepsilon s$. Since we know that Plautus altered Diphilus' $\Sigma v v a \pi o \theta v \dot{\eta} \sigma \kappa o v \tau \varepsilon s$, it would be perverse to deny the

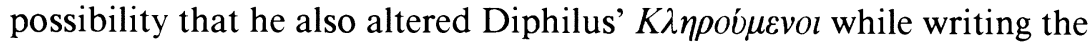
Casina. If this alteration involved not only deletions, but also contaminatio, we are in a better position to understand the change in the characters of Chalinus and Myrrhina. In other words, they could well be a composite of similar characters in two distinct plays who have different motivations. ${ }^{18}$

In order to determine whether contaminatio is present, we must

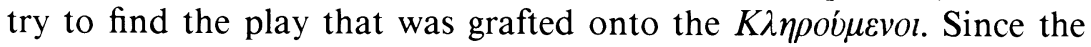
Casina is about a senex amator, we should examine the two other plays about senes amatores, the Asinaria and the Mercator. The only similarity between the Casina and the Asinaria is the fact that they both deal to some extent with senes amatores. Unlike his counterpart in the Casina, the senex in the Asinaria has a very small role and, throughout most of the play, he tries to help his son with his affair instead of blocking him. Although he is caught by his wife with his son's lover, she accomplishes this with the aid of a parasite, unlike Cleustrata who uses her own devices. Moreover, the servus callidus tricks not the father, but a trader.

The Mercator, however, corresponds closely to the Casina ${ }^{19}$ It deals with a senex amator who entrusts his neighbor with his son's

${ }^{17}$ For a discussion of contaminatio, see H. Marti, "Terenz 1909-1959," Lustrum 8 (1963) 23-27, ANRW 1.2, 1058-63, and Duckworth, op. cit., 202-208.

${ }^{18}$ Contaminatio has long been suspected in the Casina. See the summary of scholarship in G. Duckworth, "Unnamed Characters in Plautus," $C P 33$ (1938) 281, n. 57.

${ }^{19}$ Hunter, "The Aulularia of Plautus and its Greek Original," PCPh 207 (1981) 41, F. Leo, Plautinische Forschungen ${ }^{2}$ (Berlin 1912) 164, n. 1, and Webster, op. cit., 1645. 
girlfriend, thereby causing trouble between the neighbor and his wife. In the Casina, the situation is only slightly different. Here, the senex amator also entrusts his son's girlfriend to his neighbor, but the conflict centers around the senex and his own wife. The following chart indicates other similarities between these two plays.

\section{Mercator}

1. senex in love with his son's girlfriend

2. neighbor's wife insulted because the girl is in her house

3. senex takes the girl from his son

4. senex mocked by his neighbor for being a senex amator

5. neighbor acts as a middleman and takes the girl to his house

6. neighbor is trapped by his wife

7. son confronts senex through a friend

8. senex admits his error

9. senex asks his son's friend to smooth over the situation

10. senex says he has abandoned istas artis

11. senex offers to be whipped

12. cast goes inside to "make the play shorter"

13. neighbor is very concerned that his wife not be angry

\section{Casina}

senex in love with his son's girlfriend

wife of the senex insulted by his attention to the girl

senex wins the girl in a lotdrawing

senex mocked by his neighbor for being a senex amator

neighbor acts as a middleman and takes the girl into his house

senex is trapped by his wife

senex is confronted by the servus and serva

senex admits his error

senex asks his wife's friend to smooth over the situation senex promises not to seduce the girl

senex offers to be whipped senex forgiven to shorten the play

senex is very concerned that his wife not be angry

Besides similar situations, we may also point to lines in the plays which are very closely related. Leaving aside common insults that appear in both plays and may be coincidental, in the Mercator (305) we find the senex being rebuked by his neighbor with the words tun 
capite cano amas, while in the Casina the senex, in a similar situation, anticipates his neighbor's rebuke by saying cano capite ... eo addito ad compendium (518). Three passages about love and food are very close: qui amat, tamen hercle si esurit nullum esurit (Casina 795), tibi amor pro cibost (Casina 802), and nam qui amat quod amat si habet, id habet pro cibo (Mercator 744). Two jokes about hunger causing bad breath and vomiting are found in no other Plautine comedy: ${ }^{20}$ iaiunitatis plenus, anima foetida, senex hircosus tu osculere mulierem? utine adveniens vomitum excutias mulieri? (Mercator 574-77) and $O L$. fu fu! foetet tuos mihi sermo . . . $\hat{\omega} \mathbf{Z v 0}$, potin a me abeas, nisi me vis vomere hodie? (after the senex has been denied his dinner) (Casina 727, 731a$732 \mathrm{~b}){ }^{21}$ It is no accident that we find so many correlations between these two plays. A few similarities could be explained as what one would expect from Plautus' brand of generic comedy. But so many detailed correspondences make an excellent case for contaminatio. The corresponding passages of the Casina and the Mercator that cannot be ascribed to coincidence belong to lines 515-620, parts of 700800 , and large portions after 997 . A few nearly identical lines and jokes are added before the wedding scene. Therefore, we may reasonably

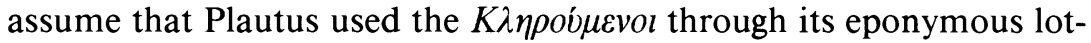
drawing scene for the beginning of the Casina and parts of the Mercator for the middle and the very end.

Terence may be invoked in objection to this theory. In the prologue to the Eunuchus (19-43), Terence explains that he was accused of stealing material from a Greek original which had already been rendered into Latin by Naevius and Plautus. In his defense, Terence claims that he did not know that the play had already been used by another Roman writer. ${ }^{22}$ The same charge cannot be leveled against

${ }^{20}$ A joke about halitosis occurs at Asinaria $894 \mathrm{ff}$., but it has nothing to do with a lack of food.

${ }^{21}$ The same type of joke may be found in Aulus Gellius, 2.23.13, quoting the comic playwright Caecilius, who wrote shortly after Plautus' death: extemplo savium dat ieiuna anima. nil peccat de savio: ut devomas, vult, quod foris potaveris. This chapter also demonstrates how far a Roman playwright might deviate from his Greek original, in this case Menander.

${ }^{22}$ It seems strange that Terence would have been so unfamiliar with Plautus' originals that he made this mistake. It is possible that he did not know that Plautus had already used Menander's Colax because it was not Plautus' main source, but, like the Mercator in the Casina, was only used piecemeal. Terence had apparently looted the 
Plautus. Even if playwrights could not utilize an original previously used by another Roman author, this did not mean that they could not rework their own material. Therefore, there is no reason why Plautus could not have used part of the Mercator in the Casina, one of his later plays ${ }^{23}$ based on a similar theme.

Having discovered the origin of the first half of the play, we must now identify the source of the wedding scene and Pardalisca's speech about Casina's madness. One of the longest cantica in the Plautine corpus (621-719), Pardalisca's speech is filled with so many mock-tragic expressions that we might think it was drawn in its entirety from the Greek original. But a joke between Pardalisca and the audience proves that most, if not all, of this scene was written by Plautus himself. First, Pardalisca runs out of the house in feigned terror. When the senex asks her what is wrong, she says:

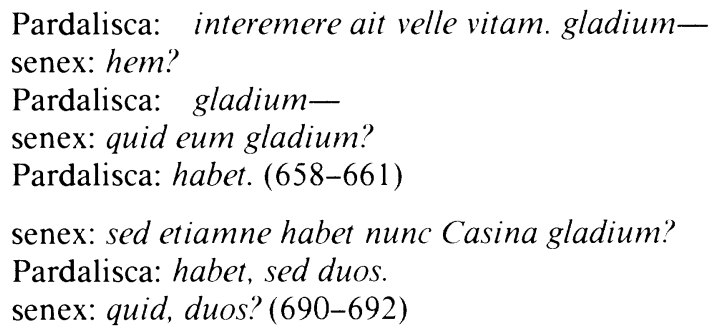

Soon afterward, Pardalisca tells the audience that the women have dressed Chalinus up as a bride and plan to give him to Olympio in place of Casina (769-770). Then, after the wedding, Olympio runs out of Alcesimus' house and, in response to Pardalisca's questioning, gives an account of his attempt to seduce Chalinus/Casina:

Olympio: oh, erat maxumum.

** haberet metui; id quaerere occepi.

*********************************

dum gladium quaero ne habeat, arripio capulum.

sed cum cogito, non habuit gladium; nam esset frigidus. (907-910)

Colax in a similar way, extracting only the roles of the parasite and braggart soldier. See Eunuchus 23-34.

${ }^{23}$ Charles Henry Buck, Jr., A Chronology of the Plays of Plautus (Baltimore 1940) 75-79 and Klaas Schutter, Quibus Annis Comoediae Plautinae Primum Actae Sint Quaeritur (Groningae 1952) 87-93. 
Pardalisca's speech has been seen by some to lack motive. ${ }^{24}$ But not only does it delay the senex, it also foreshadows the upcoming transvestite scene. ${ }^{25}$ This is accomplished by references to the gladius, a common Latin euphemism for the penis. ${ }^{26}$ At 762-770, Pardalisca tells the audience about Chalinus' disguise, so when Olympio makes reference to his body-search of Chalinus/Casina in quest of a gladius, the audience, knowing the bride's true gender, would be amused. And since this euphemism is very common, some would detect the joke in 658-692, even before Chalinus' substitution is revealed. ${ }^{27}$ Bearing in mind that Pardalisca's speech is centered around Chalinus/Casina's possession of a gladius and that Olympio's search for a gladius echoes Pardalisca's speech, we must conclude that they are mutually dependent. Clearly, Plautus wrote Pardalisca's speech and at least part of the ending of the Casina with this joke as a major consideration. And since the use of gladius as a euphemism for penis is exclusively Roman ${ }^{28}$ these scenes could not have come from a Greek original.

Finally, the wedding. The ceremony itself appears to be a combination of Greek and Roman rites. Williams ${ }^{29}$ believes that the ritual

is basically Greek. In Greece, the custom was that after the feast the bride, accompanied by the bridegroom and a close friend of the bridegroom, rode to their new home in a waggon. That was the essence of the ceremony; the waggon might further be escorted by the guests to the accompaniment of the wedding-hymn. In Rome, on the other hand, the bride was led to her new home by three young boys, accompanied

${ }^{24}$ Helen Wieand, Deception in Plautus (Boston 1929) 82, and Hough, "The Development of Plautus' Art," CP 30 (1935) 54, believe it is a result of retractatio, while Leo,

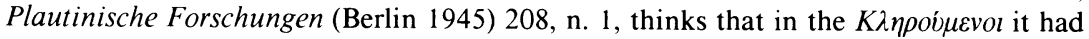
something to do with the ávajvíoslols.

${ }^{25}$ For another example of foreshadowing in the Casina, see Duckworth, $N R C$, 222.

${ }^{26}$ See J. N. Adams, The Latin Sexual Vocabulary (London 1982) 20-21.

${ }^{27}$ See Duckworth, NRC, 199.

${ }^{28}$ There is no Greek equivalent. See Duckworth, NRC, 198. Henderson, in The Maculate Muse: Obscene Language in Attic Comedy (New Haven 1975) 122, see Gípos as a euphemism for penis at Lysistrata 156 and 632. This interpretation is not necessary at 632 and does not fit the context at 156 . Aristophanes makes the women say that their husbands will forget about war if they use sexual blackmail. Even Menelaos, Lampito says, threw away his Gípos when he saw Helen's bare breasts. Surely this means that Menelaos gave up his anger and has nothing to do with masturbation.

${ }^{29}$ Gordon Williams, "Some Aspects of Roman Marriage Ceremonies and Ideals," JRS 48 (1958) 17. 
by the wedding-guests; the bridegroom did not go with her, but went ahead. Now the whole humour of the end of the Casina is that the bride is escorted by the slave Olympio, her husband, and by the lecherous old

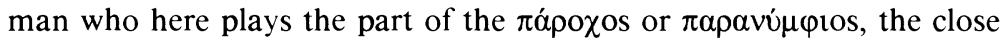
friend of the bridegroom who formed the immediate and essential escort in a Greek wedding. These two characters sing the wedding-hymn themselves, and such hymns were no part of Roman ritual. Consequently the basic dramatic conception here is Greek and must have originated with Diphilos, not with Plautus.

Although the outward appearance is Greek, the ceremony itself is Roman. Pardalisca's wedding song is a parody and an inversion of the traditional chant. ${ }^{30}$ This, of course, could not have come from the $K \lambda \eta \rho o$ v $\mu \varepsilon v o l$. And since the form is inverted, the bride is escorted over the threshold of her own home by three women instead of three boys. Therefore, this is a parody based on Roman ceremony. So to suggest that the wedding scene was in the Greek original just because some superficial aspects are Greek is unsound. Plautus may have known of Greek wedding practices from the plays he translated; and since the Casina is at least superficially about Greeks and is set in Greece, it is only natural that Plautus would portray a rite that is outwardly Greek. Underneath this, the rites are essentially Roman. In this way he is able to retain a foreign ambience while enabling the Romans to understand the humor in his inversion of the rite. In short, Plautus could perfectly well have written this scene himself. ${ }^{31}$

The aftermath of the wedding presents few problems. Olympio's lewd revelation has homosexual overtones, while the speech of the senex which follows, although lost in all the manuscripts, was surely even more obscene-if only to avoid an anticlimax. So much obscenity, so many double entendres and homosexual situations are not found in the fragments of Middle or New Comedy. Therefore, it is unlikely that this scene came from Diphilus. Duckworth ${ }^{32}$ gives us a clue to its origin:

${ }^{30} \mathrm{Cp}$. Catullus 61 .

${ }^{31}$ For a discussion of the authorship of this scene, see E. Fraenkel, Plautinisches im Plautus (Berlin 1922) 292-313 and G. Jachmann, Plautinisches und Attisches (Berlin 1931) 105-127.

${ }^{32}$ Duckworth, "Unnamed Characters," 11. 
(Fabula Atellana) were short, perhaps about three or four hundred verses ... farcical situations were frequent, and cheating and trickery and general tomfoolery played a large part. The presence of obscenity seems highly probable in popular comedy of this type, and there is some evidence of a fondness for riddles and double entendres. The meters of the ... Atellana are ... the Saturnian meter and possibly the trochaic septenarius. Music and song played an important part....

Scholars have determined that the Casina is Plautus' latest play because of the predominance of vulgarity ${ }^{33}$ and song. ${ }^{34}$ This occurs most often not only in the wedding scene, but also in the episodes from Pardalisca's song at 621 until the confession of the senex at 996about four hundred lines. Sedgwick ${ }^{35}$ has arrived at a reasonable hypothesis concerning the composition of these scenes:

... cutting out Diphilus' ending, Plautus substitutes his own, a piece of native Italian farce, which owes nothing whatever to Greek Comedy. It seems as if Plautus had come within measurable distance of grafting the old Italian on the new Greek and producing genuine Roman Comedythe culmination to which all his experiments had manifestly been tending.

Italian farce, a genre that had much in common with Fescennine verse, the nuptialia carmina ${ }^{36}$ was the perfect choice to conclude a play culminating in a marriage, especially a transvestite marriage with parallels in Atellane farce. ${ }^{37}$ Therefore, native Italian drama, not Greek comedy, was probably the main influence on Plautus' composition of the wedding scene and its aftermath.

Another change that Plautus made in his Greek original strengthens our theory about the utilization of Atellane farce at the end of the Casina: the name of the senex. In all editions since Leo's, ${ }^{38}$ he is called "Lysidamus." This appellation is derived from the scene headings of

${ }^{33}$ J. Hough, “Miscellanea Plautina: Vulgarity, Extra-Dramatic Speeches, Roman Allusions," CP 30 (1935) 43-57.

${ }^{34}$ W. B. Sedgwick, “The Dating of Plautus' Plays,” CQ 24 (1930) 102-6.

${ }^{35}$ op. cit., 106.

${ }^{36}$ See Duckworth, "Unnamed Characters," 8 and Catullus 61.121-5.

${ }^{37}$ Note such titles as Maccus Virgo and Sponsa Pappi.

${ }^{38}$ F. Leo, Plauti Comoediae (Berlin 1958). 
the Ambrosian palimpsest, a fourth-century manuscript. But the only other manuscript tradition we possess, the later Palatine recension, ${ }^{39}$ has "senex" instead of a proper name in its scene headings. ${ }^{40}$ The reading of A has, naturally, seemed preferable because it is six hundred years older than P. But Andrieu ${ }^{41}$ and Bader $^{42}$ have shown that scene headings were inserted by later editors in book texts and were not in the original performance scripts. ${ }^{43}$ As a result, the editors of $\mathrm{A}$ and $\mathrm{P}$ had to supply their own scene headings when copying from their archetypes and, for some reason, identified the main character in different ways. Therefore, the greater age of A gives it no greater weight in this matter. The name "Lysidamus" has no better authority than the generic appellation "senex." 44

Moreover, the name of the senex does not seem to appear in the play itself. As Duckworth noted ${ }^{45}$ this is an anomaly. Although minor characters often remain anonymous, prominent senes are always named. The Casina's apparent deviation from this convention could well have been what prompted the editor of A to insert the name "Lysidamus" for what appeared to be an unnamed senex in his exemplum. ${ }^{46}$ An analogous situation occurs in the scene headings of the later Palatine B. In this case, the transcriber found only the word "senex" in the scene headings of his exemplum and, convinced that such an

${ }^{39}$ To judge from its earliest representative, the codex Turnebi, this tradition is almost as accurate as A. See L. D. Reynolds, ed., Texts and Transmission: A Survey of the Latin Classics (Oxford 1983) 302-307.

${ }^{40}$ H. W. Prescott, "The Scene-Headings in the Early Recensions of Plautus," HSCP 9 (1898) 102, contends that the name of the senex was to be written in red ink, but the "rubricator neglected his duty."

${ }^{41}$ Le dialogue antique (Paris 1954) 87-206.

${ }^{42}$ Szenentitel und Szeneneinteilung bei Plautus (Diss. Tübingen 1970).

${ }^{43}$ Even a fragment of a manuscript from about the fifteenth century, Lat. Dukianus 123, has no scene headings. For the date of this manuscript, see C. Questa, "Un Codice Plautino Falsamente Creduto del Sec. X-XI," Maia 36 (1984) 151-5.

${ }^{44}$ See Andrieu, op. cit., 136-7.

${ }^{45}$ Duckworth, "Unnamed Characters," 267-282.

${ }^{46}$ Duckworth, "Unnamed Characters," n. 56, suggests that the name "Lysidamus" could have been an arbitrary choice or that the scribe took it from a copy of the $K \lambda \eta \rho o \delta \mu \varepsilon v o l$. It is extremely unlikely that the copyist of A, a fourth-century manuscript, would have had access to a copy of the Kinpó $\mu \varepsilon v o l$ since, by that time, most Greek New Comedy had been distilled into short sayings and collected in gnomic anthologies. See, for example, R. Pack, The Greek and Latin Literary Texts from Greco-Roman Egypt (Ann Arbor 1965) 92, number 1591. 
important character could not have been anonymous, searched through the play until he thought he had found a name for him-Stalicio. But this is merely a corruption of line 960: Heus, sta ilico, amator. ${ }^{47}$ In both cases the need to follow a convention overcame strict reliance on the text.

Duckworth ${ }^{48}$ tried to solve this problem by asserting that Plautus did not name the senex, suggesting that "since the senex is an excellent example of the lecherous old reprobate who is outwitted by the wily slave, it seems possible that in this case the role was clearly defined and sufficiently emphasized so that Plautus felt that no name was needed for the character." But the Plautine corpus is full of major characters who are also stereotypes and they are all named. So this is no reason for Plautus to have singled out this particular senex for anonymity.

To resolve this difficulty, we must examine a passage whose meaning and attribution have caused endless difficulty: line 814, iam oboluit Casinus procul. All translations are similar to Nixon's ${ }^{49}$ 'he's had a distant sniff of Casinus already'. This is clearly a mistranslation. Oboluit is active and can only mean 'to give off an odor'. Therefore, the line must be translated 'now Casinus has given off an odor from far away'. The proper translation limits the possible speakers of this line. The manuscripts attribute it to the senex as do Leo ${ }^{50}$ and Ernout. ${ }^{51}$ This cannot be right. If the senex spoke the line in reference to the disguised Chalinus, the masculine form "Casinus" would imply that he knew the bride was not a woman but a man. If this were the case, the deception would not have succeeded. This also prevents Olympio from speaking the line. To get around this problem, Ussing ${ }^{52}$ follows $J$ and emends Casinus to Casina. But this contradicts all other manu-

${ }^{47}$ Stalino, a corrupt form of Stalicio, appears in the headings to V, E, J, Z and F. We find a similar occurrence at line 347, where tittibilicio changes to tit tibi Stalicio. See W. Studemund, Emendationes Plautinae (Greifswald 1871) 1-7, F. Ritchl, "Quaestiones Onomatologicae Comicae" in Opuscula Philologica (Leipzig 1877) 321, and W. Lindsay, Ancient Editions of Plautus (Oxford 1904) 94. Lat. Dukianus 123 has the abbreviation STA. for the senex.

${ }^{48}$ Duckworth, "Unnamed Characters," 281-2.

${ }^{49}$ op. cit.

${ }^{50}$ Plauti Comoediae.

${ }^{51}$ Plaute (Paris 1964).

${ }^{52}$ T. Maccii Plauti Comoediae (Haunia 1887). 
scripts and has been universally rejected. Schoell ${ }^{53}$ goes even further, ignoring all the manuscripts and creating a flute player to deliver the line.

MacCary and Willcock ${ }^{54}$ attribute the line to Pardalisca. This is also unacceptable. Pardalisca would have to enter, speak a half-line in one meter, and then switch immediately to another. MacCary admits this is odd, but cites Casina 959-960 and Captivi 658 as parallels. Unfortunately, these passages do not support his argument. At Casina 959-960, Chalinus speaks a line in one meter, the senex responds, and then Chalinus speaks in a different meter. At Captivi 658, Colaphus speaks in one meter, the meter changes, but he does not speak another line. In fact, this is the only line he has in the entire play. The one conclusion we can draw from these examples is that a character may change meters rapidly, as long as the change is interrupted by a line or part of a line spoken by a different character. This would not happen if line 814 were spoken by Pardalisca. The attribution, therefore, cannot stand.

Lindsay,$^{55}$ Nixon, ${ }^{56}$ and Paratore ${ }^{57}$ have correctly attributed the line to Chalinus. We must imagine him entering in disguise, dressed as a bride. His mask would have been covered to avoid recognition by the senex and Olympio. But this would not have allowed the audience to recognize him either. So when Chalinus entered, he probably turned to the audience, delivered the line as an aside, and was recognized by his voice or at least by his mask when he pulled the veil aside. ${ }^{58}$

We have identified the speaker, but the problem of the line's meaning remains. If Chalinus is saying that he, the male Casina, is emitting an odor, there are two possible interpretations. Translators imply that Chalinus is speaking figuratively, saying that the senex has spotted him already, i.e., 'picked up his scent'. As we have seen, this is a mistranslation. ${ }^{59}$ The second possibility is to take the expression

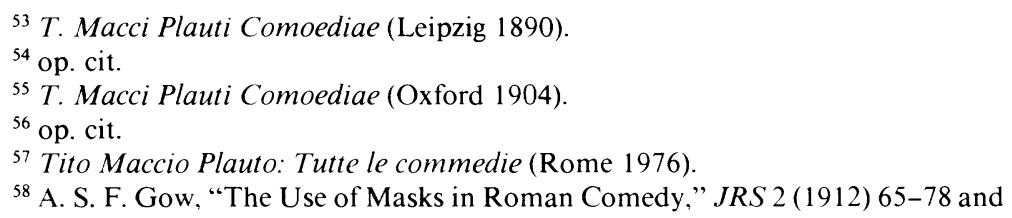
W. Beare, The Roman Stage (London 1964) 192-4, 303-9.

${ }^{59}$ The only parallel for this idiomatic usage occurs at Menaechmi 384: oboluit marsuppium huic istuc quod habes, literally, 'your wallet has given off a scent to her'. But this line has a dative of reference, while iam oboluit Casinus procul does not. Here the emphasis is on an odor in general. 
literally. Chalinus could be saying that he is emitting a feminine odor like the wife's cloak in the Menaechmi ${ }^{60}$ But this is impossible, since Chalinus refers to himself in the masculine-"Casinus." He cannot be speaking of himself, so he must be referring to someone else on stage, someone named Casinus. And the only unnamed character present is the senex. He must be Casinus.

The play contains a running joke that justifies this attribution. The senex is constantly brought to task for various odors he is emitting. In the beginning of the play (235-240), Cleustrata rebukes him for reeking of perfume. Later (727-732b) Olympio, engaged in a conversation with the senex, is sickened by his bad breath. In line 814 , Casinus has given off an odor from far off. And in the epilogue (1018), the senex is called "a goat scented with bilge water." The odors he emits become progressively stronger as the play goes on. Line 814 fits perfectly in this scheme. The breath of the senex has become so foul that Chalinus can smell it even from the door of the house.

The explanation for the similarity of the names of the senex Casinus and his wife's slavegirl Casina may be found by examining her relationship to Cleustrata. In lines $45-46$ of the prologue, we are told that when the newborn Casina was exposed, a slave found her and gave her to Cleustrata, who treated Casina as her own daughter: educavit magna industria, quasi si esset ex se nata, non multo secus. As far as we know, Cleustrata had no daughters, and so it would not be unreasonable to suppose that Casina filled this role. And, as a daughter, she would have taken the name "Casina" from that of her father, "Casinus," as Gaia takes her name from Gaius.

The first occurrence of the name "Casinus" is perfectly timed at line 814. This is the point at which the senex has given up his position in his family (as we shall see below) and thinks he is going to have sex with his surrogate daughter. The mention of his name at this juncture drives home the point that, in attempting to commit what amounts to incest, he has completely abandoned his role as father. The next time his name is mentioned is in a fragmentary section where he is being castigated by his wife, presumably for trying to have his way with Casina (888). ${ }^{61}$ The audience is again reminded of the gravity of his offence.

${ }^{60}$ Lines $164-169$.

${ }^{61}$ Studemund, op. cit., 7: (Nomen senis) videtur igitur pronuntiatum fuisse in eorum versuum aliquo, qui nunc aut omnino interciderunt aut ex parte mutili servati sunt. 
But the name "Casinus" has a deeper significance. Varro (De Lingua Latina 7.29-30) tells us that it is a form of cascus, an adjective derived from an Oscan word meaning 'old', as in the name of a town called Casinum, or Vetus Forum. But, most importantly, Varro tells us that "in several Atellane farces, this word denotes Pappus, the senex whom the Oscans call the casnar." As we have already seen, the last portion of the Casina is derived from Atellane farce. So Plautus gave the name "Casinus," the Latin form of casnar, to the senex who has been deceived and humiliated because he plays the role of his counterpart in Atellane farce, another stock character-the casnar. ${ }^{62}$ And the first mention of his name does not come until the deception modeled on Atellane farce is underway. ${ }^{63}$

It is clear that Plautus did not name the senex "Lysidamus." In choosing the name "Casinus," he has not only emphasized the filial relationship of Casina to the senex, but he has also shown that he utilized the themes of Italian farce for the conclusion of the Casina instead of those of his Greek model. Moreover, a careful examination of the rest of the Casina has shown that Plautus not only altered his Greek original, but also added large portions of a play he had previously adapted, the Mercator. ${ }^{64}$ Therefore, the only remnants of the $K \lambda \eta \rho о$ v $\mu \varepsilon v o l$ appear after the prologue and up to the end of the lotdrawing scene.

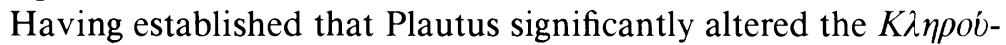
$\mu \varepsilon v o l$, we must now determine whether his adaptation is merely a loosely connected sequence of comic episodes or if each scene is an integral part of a carefully constructed plot.

An examination of the role of the senex will show that the development of his character is the thread that unifies the Casina. The original status of the senex is revealed in the beginning of the play. He exercised his patria potestas by sending his son out of the city when he

${ }^{62}$ For "speaking names," see J. C. Austin, "The Significant Name in Terence," University of Illinois Studies in Language and Literature, 7.4 1-123, and Donatus, Adelphoi 26 and Andria 226.

${ }^{63}$ Even in the first century A.D., Atellane farces were performed in Rome in Oscan and were understood by the Romans. See Strabo 5.3.6 and Tacitus Annales 4.14. Horace Epistulae 2.1.173, speaks of Dossennus, while Plautus himself mentions buccones (Bacchides 1088) and Manducus (Rudens 535). So there can be no doubt that Plautus' audience in the second century B.C. would have understood the allusion to the casnar.

${ }^{64}$ Even Leo, Geschichte der römischen Literatur, I (Berlin 1913) 126 and 136, n. 2, concluded that the Casina was largely a Roman composition. 
had become an impediment to his father's plan to have sex with the young slave girl Casina (62). Cleustrata, the wife of the senex fears her husband's power and complains about him only in whispers and only when he is absent $(195,212)$. She offers no objection to the suggestion of her neighbor, Myrrhina, that she should watch her step for fear that her husband might divorce her (211). The power of the senex is augmented by friends like Alcesimus who are willing to be of service to him and by his relatives who depend on him for legal assistance (567). At this stage he is the epitome of a strong pater familias.

But his behavior fatls short of his position in society. Cleustrata constantly reminds the audience and her husband of his advanced age (Accheruntis pabulum, nihili cana culex, decrepitum meum virum), of his decreased, even non-existent, sexual potency (vetulus vervex), and that his behavior is unbecoming a senex (senectan aetate unguentatus per vias, ignave, incedis 240 and mirum ecastor te senecta aetate officium tuom non meminisse 259). In a fit of rage, Alcesimus gives a biting description of his neighbor as illius hirqui improbi, edentuli (550). Even the senex himself realizes that a man cano capite, aetate aliena, quoi uxor sit (517) who chases young girls may be acting in a socially unacceptable manner. But he doesn't care. And from the moment he begins to abandon his proper role as the senex and pater familias for that of the iuvenis amator, he gradually loses control over his family, the respect of his friends, and his position in society.

Immediately after the senex returns from being perfumed for Casina, Cleustrata, up to this time concealing her anger, rebukes him for his unseemly behavior (238ff.). But the senex, instead of putting his wife in her place, tries to throw her off the track by feigning intense desire for her. Seeing that she won't be put off, he accepts her proposal that they plead with their respective slaves to give up their claims to marry Casina (268ff.). When both fail, he conducts a drawing of lots for possession of the girl (259ff.). Thus, when the senex gives up his role to play the iuvenis amator, he loses control over his wife. At the beginning of the play, Cleustrata was intimidated by her husband's power, but now she confronts him without fear. And the senex, instead of exercising his patria potestas, must use persuasion.

After the drawing, the over-excited senex makes some rather strange remarks to his victorious slave and ally Olympio. Ita me di bene ament ut ego vix reprimo labra ob istanc rem quin te deosculer, voluptas mea (452). Ut, quia te tango, mel mihi videor lingere (458). This is not meant as an overt homosexual advance, as most scholars 
assume ${ }^{65}$ Chalinus, Cleustrata's slave/ally, implies that it is (hodie hercle, opinor, hi conturbabunt pedes 465), but in the process makes two contradictory statements. He says that the senex likes bearded men (466), that is, old men instead of boys. But he also implies that Olympio got his job as vilicus by submitting sexually to the master, since the senex had recently offered Chalinus himself the post of atriensis presumably under similar circumstances (460). We can assume that Chalinus is a younger man because Cleustrata calls Olympio, his rival for the hand of Casina, a vetulus vervex. If Chalinus were also a senex, it is unlikely that Cleustrata would have chosen this insult because it could also be applied to Chalinus. So if the senex did prefer old men, he would not have tried to seduce the younger Chalinus. And if Chalinus were propositioned, he could not truthfully have made this statement about bearded men. Therefore, Chalinus' accusation is nothing more than slander, especially since the senex clearly states that Olympio has never had sex with him (OL. nimi' tenax es. LY. num me expertu's uspiam? 811).

Furthermore, even if these accusations were true, they would be aimed against Olympio, not the senex, since most homosexual allusions in Plautus are directed against a slave who had submitted to his master. This amatory repartee serves another purpose: the senex is making allusions to his virility through lewd suggestions. ${ }^{66}$ But more importantly, the advances of the senex and his use of voluptas mea coupled with Olympio's exclamation ut tibi morigerus hodie, ut voluptati fui (463), show us that Olympio's role is changing. Morigera is an adjective commonly used to describe a good wife ${ }^{67}$ and, in a way, (1976) 455 .

${ }^{65}$ See, for example, Cody, "The Senex Amator in Plautus' Casina," Hermes 104

${ }^{66}$ A similar situation is found in the Miles Gloriosus 1106-1113:

PY. ecquid fortis visast?

PA. omnia vis optinere.

PY. ubi matrem esse aiebat soror?

PA. cubare in navi lippam atque oculis turgidis nauclerus dixit ...

PY. quid is? ecquid fortis?

PA. abi sis hinc, nam tu quidem ad equas fuisti scitus admissarius, qui consectare qua maris qua feminas.

The adjectives that describe the senex and the miles in this situation are similar. At Casina 811, the senex is called an indomabilis equos while at Miles Gloriosus 1112 the miles is ad equas... scitus admissarius.

${ }^{67}$ Morigera: Cistellaria 175, Amphitruo 842, Casina 896, and Terence's Andria 
Olympio is acting like more of a wife than Cleustrata by cooperating with the senex instead of blocking him. As for the rather odd behavior of the senex toward Olympio, we need only recognize the similarity of his amatory behavior toward Cleustrata in the beginning of the play (229) to see that her role as wife is being assumed by Olympio. This scene, then, serves not to establish the homosexuality of the senex, but to foreshadow changes in the characters and roles of master and slave. ${ }^{68}$

Not only does the senex trade his wife for a morigerus slave, he also allows his preoccupation with Casina to make him lose a lawsuit for one of his relatives, thereby failing in his duty toward those who depend on him and who would render him service in return (563ff.). Furthermore, when confronted with the news that Casina has a sword and is intent on killing whoever marries her, the senex refuses to protect his family from danger and tries to pass the responsibility off on anyone-his wife, her ancilla, or Olympio-anyone but himself. The alienation of the senex from his family is now complete. He has shirked his responsibility as pater familias and has lost control of all those who were under his authority. He will now proceed to lose his position in society.

At first sight, his next downward step seems to be merely a stock episode in Plautine comedy. Olympio takes advantage of his master's dependence on him to assert control over the household (774ff.) and to speak to him in a free and defiant manner $(728,730,741) .{ }^{69}$ But upon closer examination, we see that Olympio has begun to act magnufice patricieque (723) while the senex, by his own admission, has become Olympio's slave (servos sum tuos 738). Moreover, Olympio is

294. Morem gerere: Menaechmi 788 and Mostellaria 189-190. See Williams, op. cit., 19-22 and 28-9.

${ }^{68}$ At Suetonius Tiberius 44.2, there is a description of a picture in which Atalanta morigeratur ore Meleager. The scholiast to Suetonius defines this as "nequitiae verbum" and cites Casina 897 as a parallel. Apparently, this is a slang term for fellatio. See Adams, op. cit., 164. Since Olympio's statement "ut tibi morigerus hodie" is surrounded by homosexual language, it is likely that the audience would have recognized this pun which is more in line with the imputations of homosexual insults against slaves mentioned above. Cf. Apuleius Apologia 74.15. For voluptas applied to a woman giving sexual pleasure, see Adams, op. cit., 197.

${ }^{69} \mathrm{~S}$. Lilja, Homosexuality in Republican Rome (Helsinki 1982) 23, suggests that Olympio can act haughtily because he is the lover of the senex. This does not seem likely because Olympio's behavior before the drawing was quite the opposite, and there is no indication that Olympio submitted sexually to his master during the play. 
about to be married, a privilege only extended to free men and an event that would seem very odd to a Roman audience, even in a comedy. ${ }^{70}$ It is clear that Plautus means us to see that the senex and Olympio are exchanging roles. The senex becomes Olympio's slave and Olympio moves from slave through morigerus wife to master.

The climactic scene of the Casina brings his final humiliation. Chalinus is disguised as Casina and married to Olympio. The senex and Olympio, pretending to take the bride to her new home in the country, sneak off next door to Alcesimus' house to enjoy themselves with their (male) bride. In his haste to seize the first fruits of the marriage before his master, Olympio tries to deflower his unwilling bride. In a rather risque speech ( $875 \mathrm{ff}$.), he recounts in great detail his shame at the unsuccessful seduction. Immediately afterward, the senex runs out of the house in despair (937ff.). He can barely stand his shame (937). He has tried to have sex with a male-he has become a cinaedus. Even worse, he suspects that Cleustrata must know about his mistake and he realizes that he has to face her (939-941). So he decides that the only way of avoiding a beating is to flee like a runaway slave (952-954).

But he is stopped by Chalinus, who accuses him of homosexuality $^{71}$ and who, as the senex fears, fusti defloccabit iam illic homo lumbos meos (967). The phrase defloccabit . . lumbos meos is ambiguous. It may mean to depilate the groin, which calls to mind the effeminate practice of softening the hair of the legs. ${ }^{72}$ But lumbus can also refer to the genitals, ${ }^{73}$ so defloccare lumbos suggests castration, if not worse. In either case, the fact that Chalinus is going to inflict this punishment with his fustis after the senex has lost his own scipio (975) makes the senex new role quite clear. ${ }^{74} \mathrm{He}$ has become a pathicus.

Ramsay MacMullen, in his article on Roman attitudes toward homosexuality, shows that homosexuality in general was looked down upon during the Republic. But some forms were worse than others. Most unacceptable was the type practiced for gain or with a social infe-

${ }^{70}$ This would explain the great attention given to the possibility of slave marriages in the prologue (67ff.).

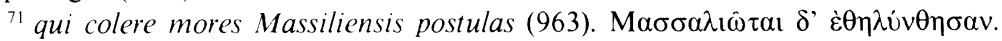
Athenaeus, Deipnosophistae $12.522 \mathrm{c}$.

${ }^{72}$ Cf. Suetonius Divus Augustus 68, Aulus Gellius, 6.12.2, and Persius 4.33-41.

${ }^{73}$ Adams, op. cit., 48.

${ }^{74}$ Almost any word for a long, rounded object may be used to refer to the penis. See the Corpus Priapeorum 9.14 telum, 25.1 sceptrum, 10.8 columna and Adams, op. cit., 14. 
rior. ${ }^{75}$ If a freeborn male adopted the role of pathicus, he was open to ridicule even from a member of the lower class. This happened, according to Cicero De Oratore 2.277, in the second century B.C. when Quintus Opimius, the consul of 154, who had been a pathicus in his youth, mocked a certain Egilius for being effeminate. The senex in the Casina is in a similar situation. He has lowered himself by taking the passive role, albeit figuratively, in a homosexual encounter with an inferior and has been ridiculed for it.

Not only has the senex come under the control of his slave, he is also forced to subordinate himself to his wife. In 978, she begins an interrogation that probably continued into a large lacuna. Its purpose is to trap the senex into admitting that he is guilty of adultery. After his confession (997), Cleustrata threatens him with physical punishment (998). Aulus Gellius, ${ }^{76}$ however, tells us that a wife had no legal or social right to abuse her husband for committing adultery. But when the situation is reversed, the husband is mulieri iudex pro censore and may inflict any punishment upon his wife, even death. Moreover, according to some manuscript readings, Cleustrata uses the oath hercle at 938 when she has caught her husband in a lie and he must admit his error. This oath ${ }^{77}$ is used only by men. Clearly, Cleustrata has changed roles. She has become both man and husband.

The humiliation of the senex is now complete. His role has gradually changed from pater familias to henpecked husband, outcast from his family, coward, slave, cinaedus, fugitive, and finally a pathicus dominated by women. Having realized his error in trying to play the part of the iuvenis amator instead of his proper role as senex and pater familias, he can symbolically regain his station through the return of his scipio $^{78}$ and pallium (1009). To remove any part of this play would

75 "Roman Attitudes to Greek Love," Historia 31 (1982) 491-492. Seneca the Elder Controversiae 4, preface 10, reports a statement of Haterius: "inpudicitia in ingenuo crimen est, in servo necessitas, in liberto officium." For the views of a Roman of the second century B.C., see the comments of Scipio Aemilianus in Macrobius 3.14.7 and Aulus Gellius 6.12.5. See also Saara Lilja, op. cit., 74.

${ }^{76}$ 10.23.4-5, quoting Marcus Cato's De Dote.

${ }^{77}$ See Aulus Gellius (11.6) and Edward C. Echols, "The Art of Classical Swearing," CJ 46 (1951) 295. Although this oath also appears at Cistellaria 52, it is spoken by Gymnasia the prostitute who has a different status than Cleustrata and is, in any case, togata. See Martial 6.64 and Horace Saturae 1.2.63 and 1.2.82.

${ }^{78}$ For the scipio as a sign of authority, see W. S. Anderson, "Chalinus Armiger in Plautus' Casina," ICS 8.1 (1983) 20. 
do irreparable harm to what is clearly an intricate and tightly constructed plot.

We may at last return to the prologue and the one word upon which so much depends: denuo. Our analysis of the play has shown that Plautus did not merely toss it in as a pleonasm for metrical purposes or as part of some incomprehensible joke. It can have only one meaning; that Plautus reworked his original to such an extent that, with the exception of lines 81-514, it must have borne little resem-

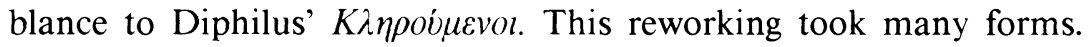

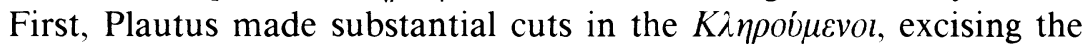
role of the iuvenis amator and, thereby, his return, the confrontation with or deception of his father, the revelation of Casina's freeborn status, and the marriage announcement. Then he added parts of the Mercator, a play he had presented approximately twenty years earlier, ${ }^{79}$ to

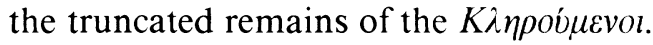

But the Casina is not merely the cutting and pasting together of two Greek comedies. It also contains a great deal of Plautus' own work. His original writing can be detected in the wedding ceremony and the mutually dependent scenes that involve a play on the word gladius. His inspiration for the form that the Casina ultimately took becomes clear with the discovery that the name of the senex amator is not "Lysidamus" but "Casinus." This Latinized form of the Oscan casnar indicates that a large part of the play has its roots not in Greek New Comedy but in Italian Atellane farce.

Merely creating a patchwork of Greek comedies and original material will not necessarily make for a good play or in itself demonstrate that Plautus was a talented writer. The end product must have a theme to provide continuity or it becomes no more than a collection of loosely connected jokes. The thread that joins the various elements of the Casina is the humiliation of the senex, the consequence of his gradual abdication of his proper role as senex and pater familias for that of iuvenis amator. Throughout the play he is degraded step by step from pater familias to henpecked husband, outcast from his family, coward, slave, cinaedus, fugitive, and pathicus while his wife arrogates his role as husband and his slave the role of wife, then master. The way in which the senex is degraded by degrees and in an orderly manner proves that Plautus did not randomly choose humorous scenes

\footnotetext{
${ }^{79}$ See Buck, op. cit., and Schutter, op. cit., for the dating.
} 


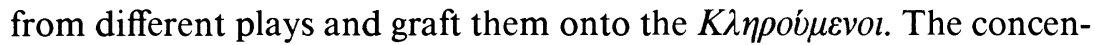
tration on continuity indicates that a great deal of effort went into developing a cohesive, comprehensible plot. Nowhere do we find the story line sacrificed for the sake of irrelevant comic episodes.

At least in the case of the Casina, we can confirm Hough's and Sedgwick's theories that Plautus' later plays show a greater tendency to depart from their Greek originals. Apparently experience taught him that his plays would have greater appeal the more he moved away from translation and began to incorporate his own material, including some elements of Italian comedy. Ancient critics bear this out, especially Volcacius Sedigitus (Aulus Gellius 15.24) who lists Plautus as one of the ten great writers of Roman Comedy, second only to Caecilius. Terence, whose plays more closely echo their Greek originals, is rated only sixth.

Instead of searching for the ever elusive Greek originals behind Plautus' comedies we should try to discover how he made his plays so appealing to the Roman public, no matter what their social position. Surely this was no small task. He had to satisfy the farmer with barnyard humor and simple jokes while holding the attention of the aristocrat with subtle witticisms and a coherent plot. In many cases, this required a wholesale revision of his source involving not only editing, but also the composition of entire scenes. Admittedly, in some of his earlier plays these additions took the form of simple jokes or unimportant linking monologues. But in the Casina, every piece is an integral part of the whole which cannot be removed without damaging the overall framework. Such a tightly structured play is not the work of a hack, but of a mature, talented writer. The Casina is not essentially an

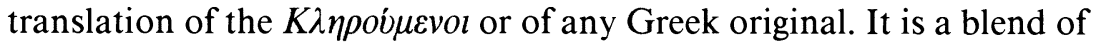
various elements, and it may well be superior to each of the sources from which its substance is derived. ${ }^{80}$

University of Texas, Austin

SHAWN O'BRYHIM

${ }^{80}$ I would like to thank M. Gwyn Morgan and Douglass Parker for their valuable advice and criticism. Any faults are, of course, my own. 